\title{
Manufacturing Process And Tonase Calculation On Bumper Rear Axle Bracket Rh
}

\author{
${ }^{1}$ Febrian Aliandi, ${ }^{2}$ Abdul Muchlis, ${ }^{3}$ Sandy Suryady \\ 1,2,3 Department of Mechanical Engineering, Faculty of Industrial Technology, \\ Gunadarma University, Indonesia \\ *Correspending Author : \\ Email : muchlis07@staff.gunadarma.ac.id
}

\begin{abstract}
Rear Axle Bumper Bracket is a non-frame part of the car that functions to connect the bumper itself to the rear axle and to withstand collisions and also reduce collisions. Rear Axle Bumper Brackets are commonly used for vehicle components. This writing aims to determine the process of making the Rear Axle RH Bumper Bracket and the total force in the blanking (cutting) process and also in the bending (bending) process of the RH Rear Axle Bumper Bracket Lower Part. Bumper Rear Axle Bracket RH is made by going through a material formation process by cutting blanking and bending, followed by a welding process using spot welding to the painting stage using a powder coating method of dipping. Based on the results of calculations using SPH 440 OD material for the main material for making Bracket Bumper Rear Axle RH Lower Part, it was found that the amount of tonnage that occurred in the blanking process (cutting) was 84.09 Tons with an added reserve force of 8.41 Tons with a value of 84.09 Tons. safety factor of 1.3 which has been standardized on the use of static loads so as to produce the capacity of the press machine needed for the blanking process (cutting) which is 120.25 tons with the actual press machine used of 110 tons. For the bending process, it can be done with a total bending force of 27.19 tons with the added pad force in the bending process of 6.8 tons so that the total force on the Press machine needed for the bending process is 34 tons with the actual press machine. used is 110 tons.
\end{abstract}

Keywords: Bracket, Manufacturing, Automotive, Welding, Stamping

\section{INTRODUCTION}

The component of the power transfer system used to transfer power from the axle (differential) to the rear drive wheels is the Axle Shaft. Therefore, the axle shaft is commonly referred to as a drive system which can be categorized into frame parts and non-frame parts which are frameless components or parts that do not require a foundation to make it like a chassis. One component of the power transfer system that is used to transfer power from the axle (differential) to the rear drive wheels is the Axle Shaft. Therefore, the axle shaft is commonly referred to as a drive system which can be categorized into frame parts and nonframe parts which are frameless components or parts that do not require a foundation to make it like a chassis.

Bumper Bracket Rear Axle RH is a non frame sub assy part which is located on the rear axle of fourwheeled vehicles (rear axle). Like the function of the bracket in general, namely as a support for one component with other components, the Rear Axle RH Bumper Bracket serves to support the bumper part itself with the rear axle (rear axle). workmanship with a 110 Ton Press machine which is used to make Bracket Bumper Rear Axle RH Lower Part products. The production process of the Rear Axle RH Bumper Bracket begins with the selection of Cutting Steel Blank SPH 440 OD and SPHC PO Steel Sheet materials, then the process of forming a plate sheet that is formed into parts by means of blanking, then the bending process The next process is the welding and painting process.

\section{Theoretical}

Bracket Axle Rear Bumper is part of non frame part of the car bumper parts serves to connect itself to the rear axle (rear axle) as well as for withstand impact and also absorb impact. Rear Axle Bumper Brackets are commonly used for vehicle components. In general, the Rear Axle Bumper Bracket is produced 
in 2 types of units, namely the RH Rear Axle Bumper Bracket for the right side and the LH Rear Axle Bumper Bracket for the left side. Both have almost the same design and dimensions, the only difference lies in the height of the flange. In the Rear Axle RH Bumper Bracket, the flange on the right side is lower than the left side, and vice versa, on the LH Rear Axle Bumper Bracket, the left side flange is lower than the right side. In one Bracket Bumper Rear Axle product itself, it consists of 2 parts, namely Lower Part and Upper Part. At the bottom, there is a Lower Part that functions to support the Upper Part which is located right at the top so that it can adjust its work function when it becomes a whole part.

\section{Materials The}

materials used for the manufacture of RH Bumper Rear Axle Brackets are of 2 types, namely SPH 440 OD material and SPH 440 OD iron plate which are included in the category of hot rolled steel plate. The specifications for SPH 440 OD are contained in the JIS G3113 standard.

Table 1. Composition of SPH440 [1]

\begin{tabular}{|l|c|c|c|c|c|}
\hline \multirow{2}{*}{ Material } & \multicolumn{5}{|c|}{ Chemical Composition } \\
\cline { 2 - 6 } & C & Mn & P & S & Si \\
\hline \multirow{2}{*}{ SPH440 } & 0.16 & 1.03 & 0.014 & 0.003 & 0.23 \\
\hline
\end{tabular}

Table 2. Mechanical Properties of SPH 440 OD [1].

\begin{tabular}{|c|c|c|c|c|c|c|c|c|}
\hline \multirow[b]{2}{*}{ Matertat } & \multicolumn{4}{|c|}{ Elangztime $\%$} & \multicolumn{4}{|c|}{ Tewile Serroush (Mipa) } \\
\hline & $\begin{array}{c}\text { Takkaros } \\
2.5 a n a n\end{array}$ & $\begin{array}{c}\text { Thichasus } \\
\text { 3.2man }\end{array}$ & $\begin{array}{c}\text { Thixkarn } \\
\text { 3.0min }\end{array}$ & $\begin{array}{c}\text { Thichars } \\
\text { 4.8ne }\end{array}$ & $\begin{array}{l}\text { Thinkaen } \\
2.5 \mathrm{me}\end{array}$ & $\begin{array}{c}\text { nesarn } \\
\text { 3.2min }\end{array}$ & $\begin{array}{c}\text { TMichars } \\
\text { 3.0min }\end{array}$ & $\begin{array}{c}\text { Thirtarn } \\
4.0 \mathrm{~mm}\end{array}$ \\
\hline SPLA40 & $56 \min$. & 29 min & 28 min & 31 an & 485 เมอ & 406495 & 596491 & 50050 \\
\hline
\end{tabular}

Table 3. Chemical Composition of SPHC-PO [2].

\begin{tabular}{|c|c|c|c|c|}
\hline \multirow{2}{*}{ Material } & \multicolumn{4}{|c|}{ Chemical Composition \% } \\
\hline & C & Mn & $\mathbf{P}$ & $\mathbf{S}$ \\
\hline \multirow{2}{*}{$\triangle P H C$} & 0.15 & 0.60 & 0.050 & 0.050 \\
\hline & $\max$ & max. & $\max$. & $\max$. \\
\hline \multirow{2}{*}{ SPHD } & 0.10 & 0.50 & 0.040 & 0.040 \\
\hline & mas. & $\max$. & $\max$. & $\max$. \\
\hline \multirow{2}{*}{ SPHE } & 0.10 & 0.50 & 0.030 & 0.035 \\
\hline & $\max$ & $\max$. & max & $\max$. \\
\hline
\end{tabular}

Table 4. Mechanical Properties of SPHC-PO [2].

\begin{tabular}{|c|c|c|c|c|c|c|c|c|c|c|c|c|}
\hline \multirow[b]{3}{*}{ Metorstal } & \multirow{3}{*}{ 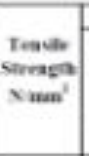 } & \multicolumn{6}{|c|}{ 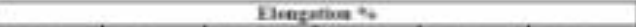 } & \multirow{3}{*}{$\begin{array}{l}\text { Tenall } \\
\text { Test } \\
\text { newr }\end{array}$} & \multicolumn{4}{|c|}{ Bratateary } \\
\hline & & \multirow{2}{*}{ 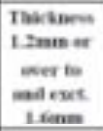 } & \multirow[b]{2}{*}{ 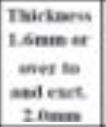 } & \multirow[b]{2}{*}{ 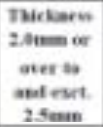 } & \multirow[b]{2}{*}{ 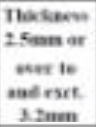 } & \multirow[b]{2}{*}{ 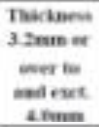 } & \multirow{2}{*}{$\begin{array}{l}\text { Thiclaern } \\
\text { chume of } \\
\text { seres }\end{array}$} & & \multirow[b]{2}{*}{ 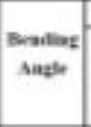 } & \multicolumn{2}{|c|}{ 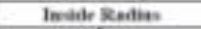 } & \multirow{2}{*}{ 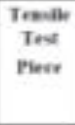 } \\
\hline & & & & & & & & & & 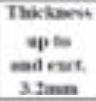 & 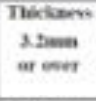 & \\
\hline SPAC & $290 \mathrm{~min}$ & $27 \min$ & 29 min. & $29 \min$ & $9 \mathrm{man}$ & 31 min. & $31 \operatorname{man}$ & \multirow{3}{*}{$\begin{array}{l}\text { No.s an } \\
\text { matues } \\
\text { Artection }\end{array}$} & 180 & $\begin{array}{l}\text { Fis is } \\
\text { inelf }\end{array}$ & $\begin{array}{c}\text { Thescaneis } \\
\text { xes }\end{array}$ & \multirow{3}{*}{$\begin{array}{l}\text { Xo } 3 \text { in } \\
\text { mities } \\
\text { Ainestion }\end{array}$} \\
\hline SPHD & $230 \mathrm{~min}$ & $30 \mathrm{um}$ & 32 aie. & $33 \operatorname{man}$ & $39 \operatorname{man}$ & 39 man. & 39 man. & & - & - & - & \\
\hline SFHE & $290 \mathrm{~min}$ & 31 man. & $33 \operatorname{man}$ & $35 \operatorname{man}$ & $37 \mathrm{am}$ & 39 an. & $41 \operatorname{man}$ & & - & - & - & \\
\hline
\end{tabular}

To calculate the total tonnage required in theprocess blanking, what you need to know is:

a. Circumference of the Geometric Shape of the Part to be Blanking (U)

b. Material Thickness ( $\mathrm{t}$ )

c. Tensile Strength(TensileStrength)(TS)

Having obtained the circumference part in the search for a large blanking cutting force can be calculated using the following equation:

$$
\mathrm{Fs}=\mathrm{U} \times \mathrm{Sx} 0.8 \times \mathrm{TS}
$$

Description:

Fs $=$ Style Cut $(\mathrm{N})$

$\mathrm{U}=$ Circumference or cutting length (mm)

$\mathrm{TS}=$ Tensile Stress $\left(\mathrm{N} / \mathrm{mm}^{2}\right)$

$\mathrm{s}=$ Material Thickness $(\mathrm{mm})$ 
Next, look for stripping force, which is an additional force with the aim of being a backup force in determining the tonnage of the press to be used. Fst $=(5 \%-10 \%) \times \mathrm{Fs}$

Description:

Fst $=$ Stripping Force $(\mathrm{N})$

Fs $=$ Cutting Force $(\mathrm{N})$

By knowing the cutting force and stripping force, the capacity of the press machine (press machine capacity) can be determined by the formula :

$\mathrm{Pm}=(\mathrm{Fs}+\mathrm{Fst}) \mathrm{x}(\mathrm{Sf})$

Information:

$\mathrm{Pm}=$ Press Machine Capacity $(\mathrm{N})$

$\mathrm{Fs}=$ Cutting Force $(\mathrm{N})$

Fst $=$ Force Stripping $(\mathrm{N})$

$\mathrm{Sf}=$ Safety Factor

For the safety factor, it can be seen through thetable safety factor The recommended amount is 1.3.Calculating the Total Tonnage required in the bending process, the things that need to be known are:

a. Plate Width in the Bending Axis Direction (B)

b. Plate Thickness (t)

c. Material Tensile Strength (TS)

d. Bending Force Constant $(\mathrm{t}=0-3 \mathrm{~mm}$, then $\mathrm{c}=1.0$, if $\mathrm{t}=>3$, then $\mathrm{c}=2.0)$ The following is the formula forForce Bending according to the shape of the bending, namely: a.Force Bending $\mathrm{U}$

\section{$\mathrm{FB}_{\mathrm{U}}=\frac{c}{3} \times(2 \mathrm{~B}) \times \mathrm{x} \times \mathrm{TS}$}

Description:

FBU $=$ U Bending Force $(\mathrm{N})$

$\mathrm{C}=$ Bending Constant (If $\mathrm{t}=0-3 \mathrm{~mm}$, then $\mathrm{c}=1.0$, if $\mathrm{t}=>3$, then $\mathrm{c}=2.0) \mathrm{B}=$ Plate Width in

the Bending Axis Direction (mm)

$\mathrm{t}=$ Plate Thickness $(\mathrm{mm})$

$\mathrm{TS}=$ Material Tensile Strength $(\mathrm{MPa})$

b.Force Bending L

\section{FBU $=\frac{c}{3} \times(B) \times t \times$ TS}

Description:

$\mathrm{FBL}=$ Bending Force $\mathrm{L}(\mathrm{N})$

$\mathrm{C}=$ Bending Constant (If $\mathrm{t}=0-3 \mathrm{~mm}$, then $\mathrm{c}=1.0$, if $\mathrm{t}=>3$, then $\mathrm{c}=2.0) \mathrm{B}=$ Plate Width in the

Bending Axis Direction ( $\mathrm{mm}$ )

$\mathrm{t}=$ Plate Thickness $(\mathrm{mm})$

$\mathrm{TS}=$ Material Tensile Strength $(\mathrm{MPa})$

Note:

After getting the bending force on each, the total can be calculated.

$\mathrm{TBF}=$ TotalForce Bending $(\mathrm{N})$

$\mathrm{FB} 1=$ Force Bending $1(\mathrm{~N})$

FB2 $=$ Force Bending $2(\mathrm{~N})$

$\mathrm{FBn}=$ Force Bending $\mathrm{n}(\mathrm{N})$

In the bending process, there is a pad force or commonly called a pad force which is used to hold the

Note: material todeform to a shape.

Fpad $=$ Pad Force or Pad Force $(\mathrm{N})$

$\mathrm{TBF}=$ Total Bending Force $(\mathrm{N})$

After obtaining the Pad Force value, the total tonnage required for the bending process can be immediately 


$$
\text { calculated using the sum of the total forces. } \mathrm{FB}_{\mathrm{TOT}}=\mathrm{TB}_{\mathrm{F}}+\mathrm{F}_{\text {pad }} \text {. }
$$

Note:

FBTOT $=$ Total Bending Force $(\mathrm{N})$

Fpad $=$ Pad Force or Pad Force $(\mathrm{N})$

$\mathrm{TBF}=$ Total Bending Force $(\mathrm{N})$

\section{METHODS}

This research was conducted in stages called the flowchart of the V-Roll cover making process so as not to deviate from the goal writing.

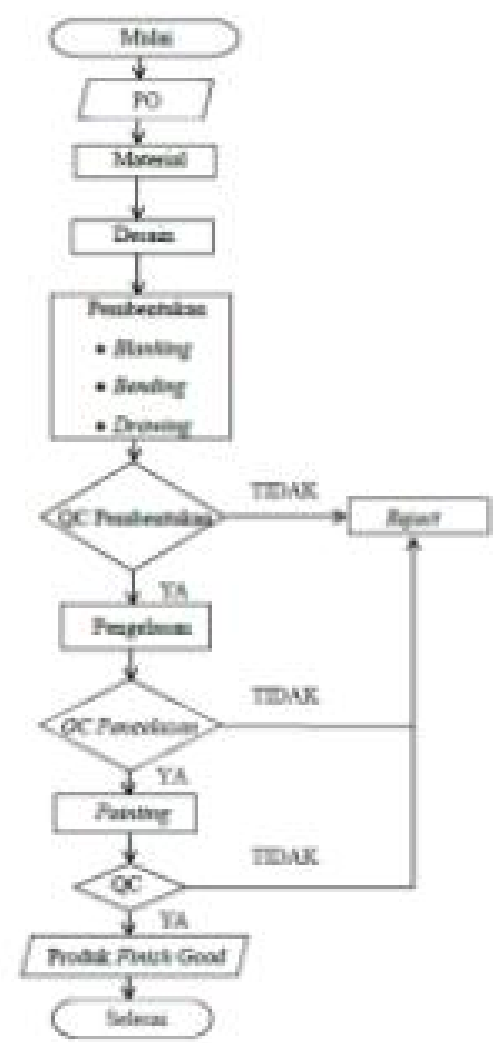

Fig 1. Flowchart of the Manufacturing Process The Rear AxleBumper Bracket RH

main materials used for the RH Rear Axle Bumper Bracket manufacturing process are Cutting Steel Blank SPH 440 OD and Steel Sheet SPHC PO.

Table 6. Rear Axle RH Bumper Bracket Material

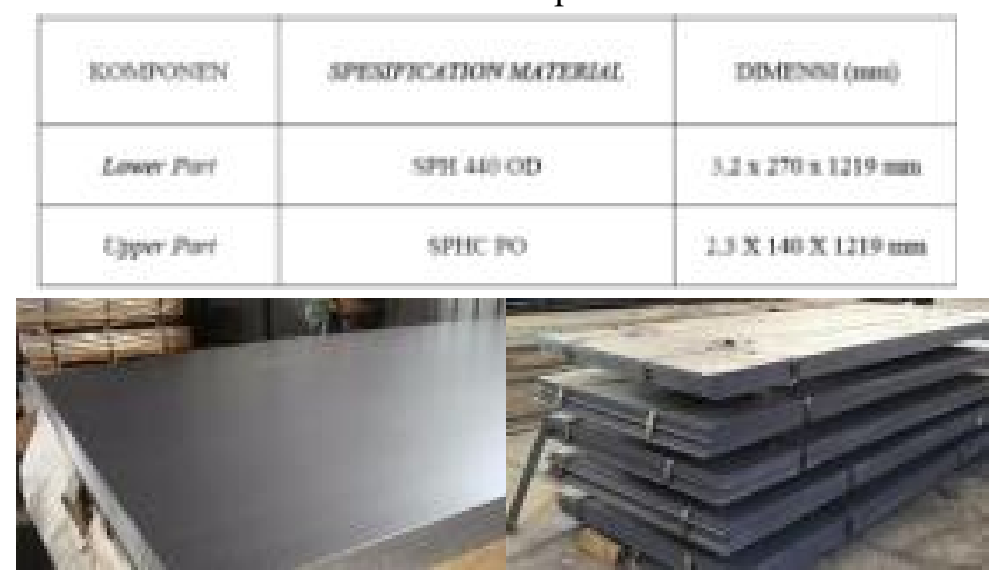

(a)

(b)

Fig 2. Material (a) SPH 440 OD Iron. (b) Steel SPHC PO

\section{Design (Drawing Process) The}

drawing process or product design process is carried out in accordance with the manufacturing standards of the RH Bumper Rear Axle Bracket. 

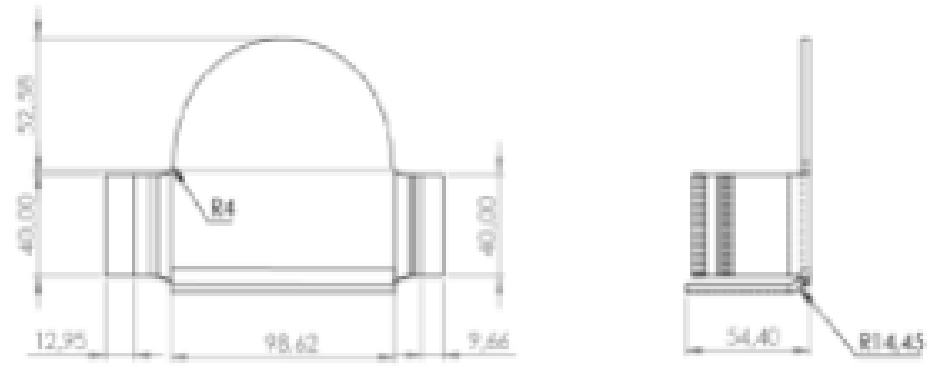

Fig 3. Rear Axle Bumper Bracket RH Lower Part (mm)
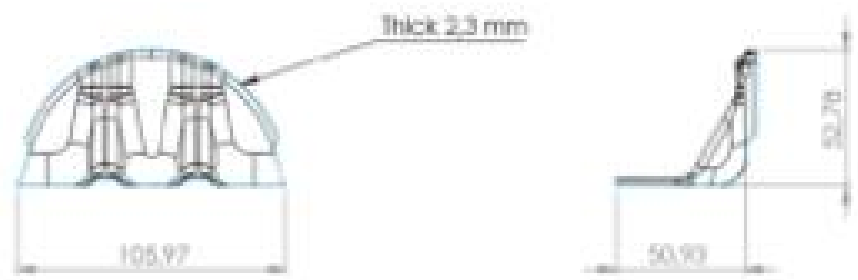

Fig 4. Rear Axle Bumper Bracket RH Upper Part (mm)
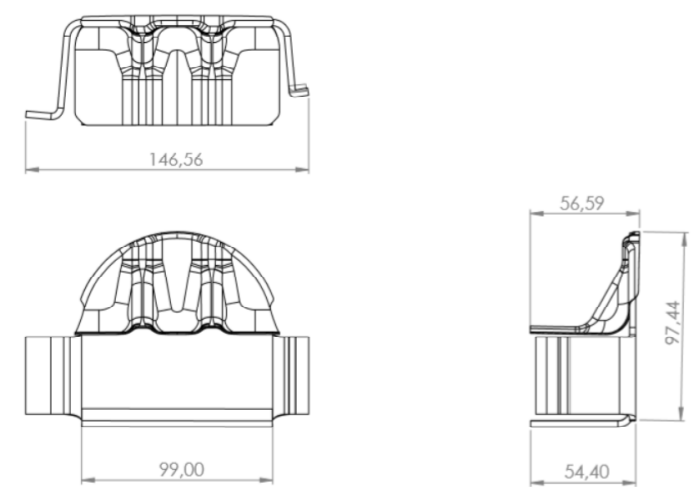

\section{Formation (Forming)}

Fig 5. Rear Axle Bumper Bracket RH (mm).

Forming metal forming process is done by dividing the raw material used pieces or sets of parts that will be assembled (assembly)

on the next line. This process includes Blanking (cutting blanks), Bending (bending) and Drawing. The following are the processes:

\section{Blanking}

Blanking is a process of preparing material to be cut according to the required dimensions, aiming to get the cut results and the rest of the pieces or commonly called scrap can be discarded. The blanking process is carried out by pressing the plate or metal sheet with 2 dies consisting of upper dies and lower dies.

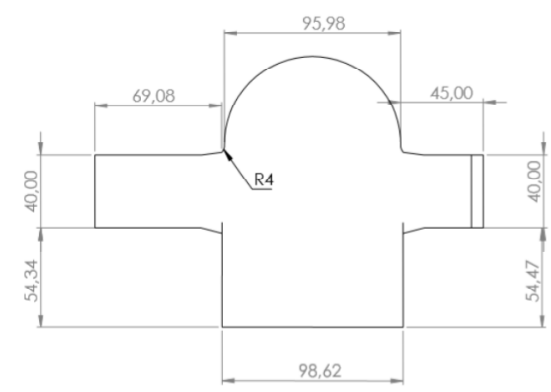

(a)

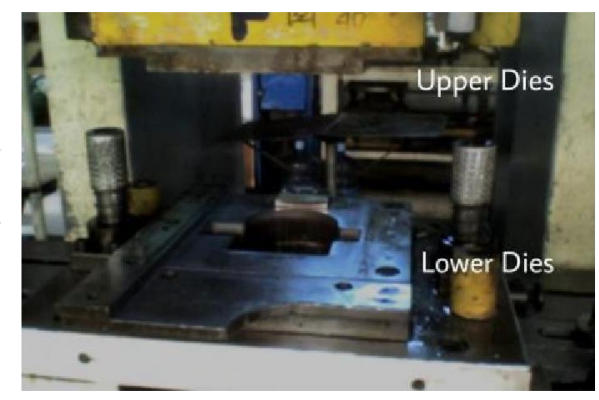

(b)

Fig 6. (a) Layout of Blanking Bracket Bumper Rear Axle RH Lower Part (mm). (b) Dies Blanking Bracket Bumper Rear Axle RH Lower Part 


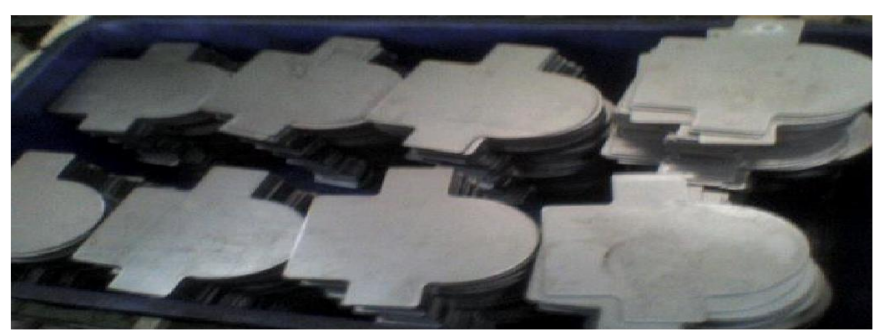

Fig 7.Result of Blanking Bracket Bumper Rear Axle RH Lower Part

\section{Bending}

This bending process is carried out on SPH 440 OD material for the manufacture of Lower Part Bracket Bumper Rear Axle RH. The machine used to bend the blanking of the Bracket Bumper Rear Axle RH Lower Part press machine with a pressure of 110 tons or $1078.7315 \mathrm{kN}$ with a hydraulic pressing system.

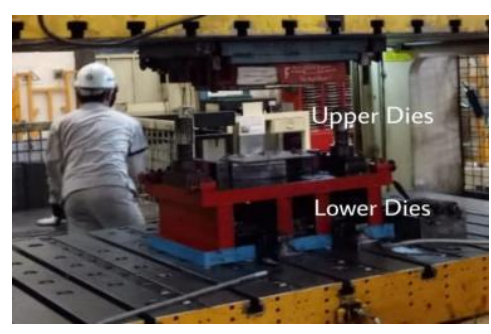

(a)

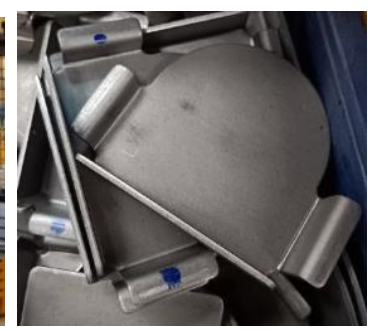

(b)

Fig 8. (a) Bending Dies Bracket Bumper Rear Axle RH Lower Part, (b) Results of Bending Bracket Bumper Rear Axle RH Lower Part

In the process, there is a bending angle profile on the lower part of the bumper rear axle bracket that can seen in the following table:

Table 7. Bending Profile of the Rear Axle RH Bumper Bracket Lower Part

\begin{tabular}{|c|c|c|c|}
\hline Bagian & Ukuran (mm) & Radius (mm) & Angle \\
\hline Arm kiri & $37,58 \times 3,2$ & 9,20 & $90^{\circ}$ \\
\hline Flange kiri & $12,95 \times 3,2$ & 6,20 & $90^{\circ}$ \\
\hline Arm kanan & $25,92 \times 3,2$ & 9,20 & $90^{\circ}$ \\
\hline Flange kanan & $9,66 \times 3,2$ & 3,0 & $90^{\circ}$ \\
\hline Arm bawah & $39,95 \times 3,2$ & 14,45 & $90^{\circ}$ \\
\hline
\end{tabular}

\section{Drawing}

machine used to draw the blanking of the Rear Axle RH Upper Part Bumper Bracket is a press machine OBW200-3 with a pressure of 200 Tons or $1961.33 \mathrm{kN}$ with hydraulic suppression system.

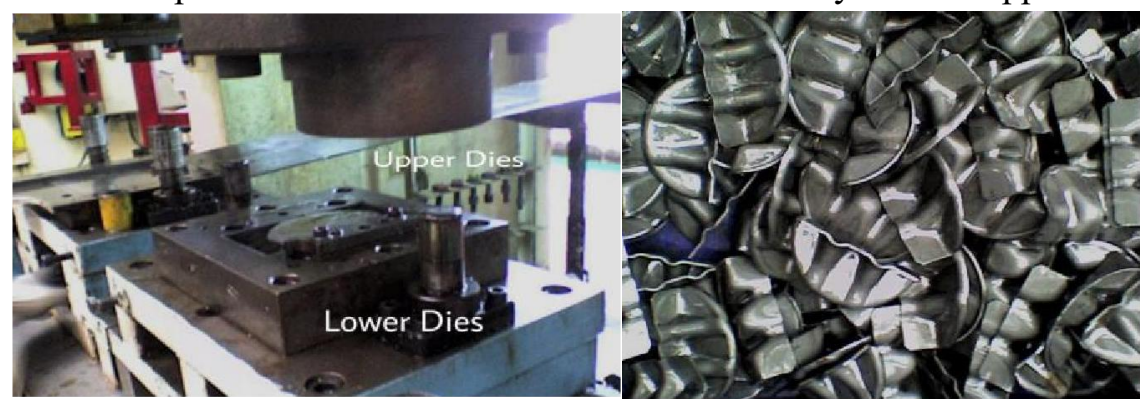

(a) (b)

Fig 9. (a) Drawing Dies Bumper Bracket RH Rear Axle Upper Part, (b) Results Bracket Drawing

Bumper RH Rear Axle Upper Part 


\section{Quality Control}

Process Quality Control Formation done before proceeding to the welding.

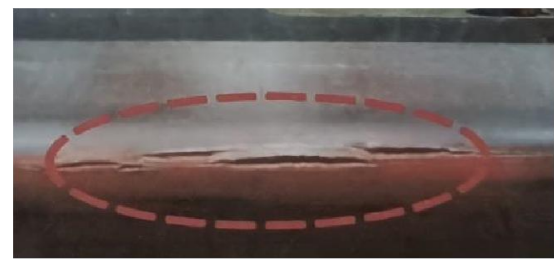

(a)

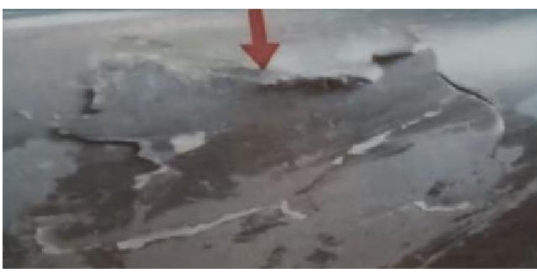

(c)

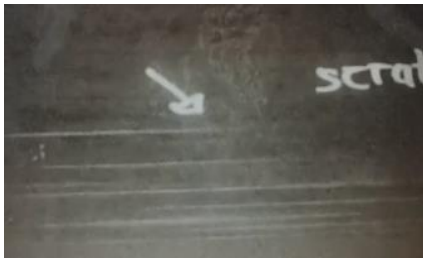

(b)

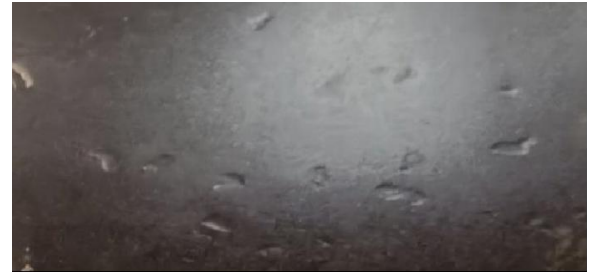

(d)

Fig 10. kinds of parts do not pass QC (a) Crack, (b) Scratch, (c) Lamination, (d) Pork mark The causes of parts not passing the test can be explained below, namely:

\section{a. Crack}

This is due to a material whose mechanical properties have decreased or it could be because the dies used have properties that are too hard for the material to be formed. Another cause is that it occurs due to forging errors and also the design of the mold (dies).

\section{b. Scratch}

The cause of this can occur because at the time of forging, the plate material is scratched by the die (dies). If there is a scratch on the product, the item will be rejected.

\section{c. Lamination}

Lamination (peeling) on the sheet metal layer after the deformation process with a press machine. Peeling of this plate is rare.

\section{d. Pork marks}

Pork marks or commonly known as pockmarks. This pork mark can be caused by an unclean plate surface during the forging process with a press machine, so that dirt, such as scrap, is forged, resulting in pork marks.

\section{Welding}

This process is carried out by welding the material that has been formed into a Bumper Rear Axle Bracket RH. This welding process is carried out by Spot Welding, which is a type of workpiece connection which in principle uses a lap joint type with point welding. In this process, the Dengensha NWC-900 Series Spot Welding Machine is used.

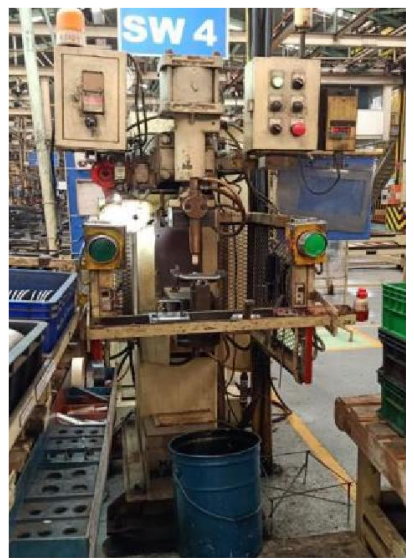

(a)

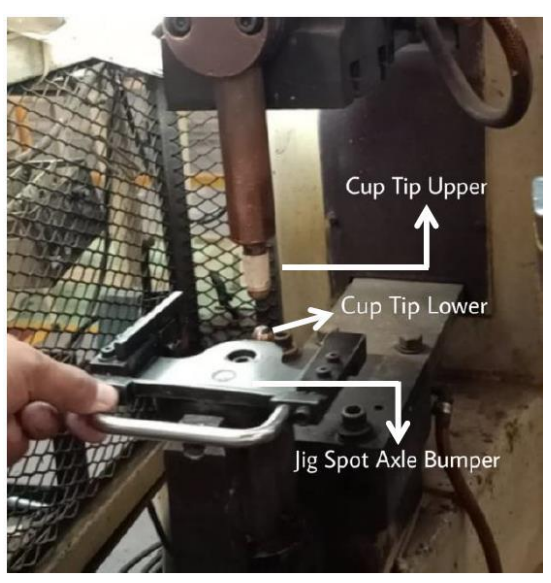

(b)

Fig 11. (a) Dengensha NWC-900 Series Spot Welding Machine, (b) Spot Welding Machine Tooling Bracket Bumper Rear Axle RH The 
following are the process parameters of the spot welding machine used.

Table 8. Spot Welding Process Parameters

\begin{tabular}{|c|c|c|c|c|}
\hline \multicolumn{5}{|c|}{ PROCESS PARAMETER } \\
\cline { 3 - 5 } \multicolumn{2}{|c|}{ PART NAME } & $\begin{array}{c}\text { Current } \\
(\mathrm{kA})\end{array}$ & $\begin{array}{c}\text { Time } \\
(\mathrm{s})\end{array}$ & $\begin{array}{c}\text { Force } \\
(\mathrm{kN})\end{array}$ \\
\hline \multirow{3}{*}{ Input Weld Machine } & Output & $8.1-9.9$ & $22.5-27.5$ & $4.5-5.6$ \\
\cline { 2 - 5 } & Method & \multicolumn{2}{|c|}{ Weld Scope } & Load Cell \\
\hline
\end{tabular}

The next process is a visual check on the spot welding section which can be seen in Figure 12.

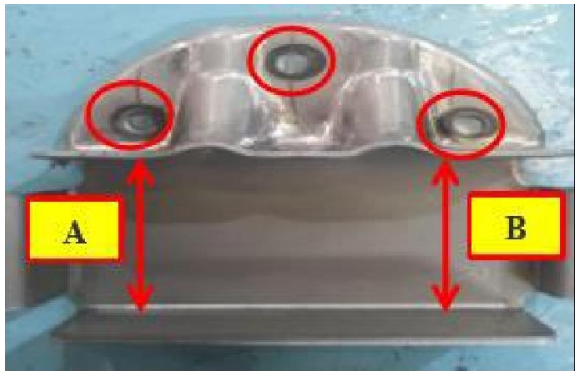

Fig 12. Visual Check Using Dermagraph

\section{Tonnage Calculation on Work with aMachine Press 110 Ton}

In the process that occurs on the press machine, especially on the There are several things that must be taken into account in the blanking and bending process to produce a good and optimal product. Some of these include cutting forces and bending forces.

\section{(Cutting ForceCutting Force)}

$$
\text { Fs } \quad=\mathrm{U} \times \mathrm{s} \times 0,8 \times \mathrm{TS}
$$

Part geometry.

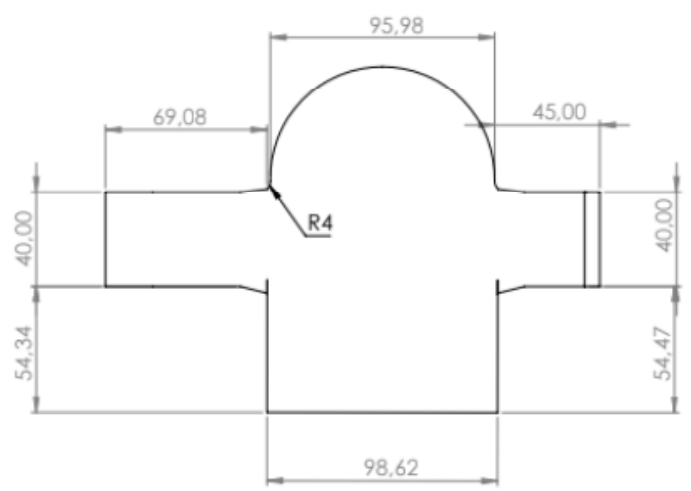

Fig 13. Dimensions of product circumference ( $\mathrm{mm})$

\section{Calculating Perimeter of Blanking Geometry}

$\mathrm{U}=$ Perimeter of Geometry + Perimeter of Semicircle

$=(\mathrm{K}$. geometry $)+(\mathrm{d})$

$=(98.62+54.47+45.0+40.0+45.0+69.08+40.0+69.08+54.34)+($ x 3.14 x 95.98) $\mathrm{mm}$

$=515.59+(150.6886) \mathrm{mm}$

$=666.28 \mathrm{~mm}$

Calculating Total Press Machine Tonnage

$\mathrm{Fs}=666.28 \times 3.2 \times 0.8 \times 493$

$=840896.89 \mathrm{~N}$

$=84089.69 \mathrm{~kg}=84.09$ Ton

So, the total tonnage of the press machine required in the blanking cutting process is 84.09 Tons with the actual machine used is 110 tons. 


\section{Calculating theForce Stripping}

Calculation of theforce stripping is an additional force with the aim of being a backup force in determining the tonnage of themachine press used.

$$
\begin{aligned}
\text { Fst }= & (5 \%-10 \%) \times \text { Fs } \\
& =(0.1) \times(84.09 \text { Ton }) \\
& =8.41 \text { Ton }
\end{aligned}
$$

Press Machine Capacity

$$
\begin{aligned}
\mathrm{Pm}= & (\mathrm{Fs}+\mathrm{Fst}) \times(\mathrm{Sf}) \\
& =(84.09 \text { Tons }+8.41 \text { Tons }) \times 1.3 \\
& =92.50 \times 1.3 \\
& =120.25 \text { Tons }
\end{aligned}
$$

So, the total reserve cutting force (plus stripping force) required for the blanking cutting process is equal to 120.25 Tons with the actual machine used is 110 Tons.

Style Bending(BendingForce)

$$
\begin{aligned}
\mathrm{FB}_{\mathrm{L}} & =\frac{C}{3} \times \mathrm{B} \times \mathrm{t} \times \mathrm{TS} \\
\mathrm{FB}_{\mathrm{U}} & =\frac{C}{3} \mathrm{x}(2 \mathrm{~B}) \times \mathrm{t} \times \mathrm{TS}
\end{aligned}
$$

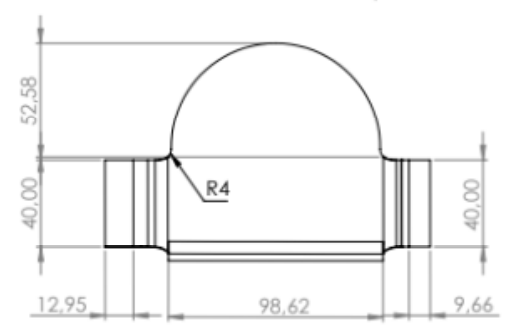

Fig 14. Bending Dimensions (mm)

\section{Calculating theforce Bending $\mathbf{U}$}

$$
\begin{aligned}
\mathrm{FB}_{\mathrm{U}} & =\frac{C}{3} \times(2 \mathrm{~B}) \times \mathrm{t} \times \mathrm{TS} \\
& =\frac{2.0}{3} \times(2 \times 40) \times 3.2 \times 493 \\
& =84138,67 \mathrm{~N} \\
& =8413,87 \mathrm{~kg}=8,41 \mathrm{Ton}
\end{aligned}
$$

CalculatingBending Style L Left and Right Side (B1 = B2)

$$
\begin{aligned}
\mathrm{FB}_{\mathrm{L} 12} & =2\left(\frac{C}{3} \times \mathrm{B} \times \mathrm{t} \times \mathrm{TS}\right) \\
& =2\left(\frac{2.0}{3} \times 40 \times 3.2 \times 493\right) \\
& =2(42069,33) \\
& =84138,66 \mathrm{~N} \\
& =8413,87 \mathrm{~kg}=8,41 \mathrm{Ton}
\end{aligned}
$$

\section{Counting Down Side L Style Bending}

$$
\begin{aligned}
\mathrm{FB}_{\mathrm{L} 3} & =\frac{C}{3} \times \mathrm{B} \times \mathrm{t} \times \mathrm{TS} \\
& =\frac{2.0}{3} \times 98.62 \times 3.2 \times 493 \\
& =103721,94 \mathrm{~N} \\
& =10372,19 \mathrm{~kg}=10,37 \text { Ton }
\end{aligned}
$$




\section{Calculated style Bending}

$\mathrm{T}_{\mathrm{BF}}$

$=\mathrm{FB}_{\mathrm{U}}+\mathrm{FB}_{\mathrm{L} 12}+\mathrm{FB}_{\mathrm{L} 3}$

$=8,41$ Ton $+8,41$ Ton $+10,37$ Ton

$=27,19$ Ton

Calculating Total Machine Press Bending

\section{Total CalculatedstylePad}

$$
\begin{aligned}
\mathrm{F}_{\text {pad }} & =25 \% \times \mathrm{T}_{\mathrm{BF}} \\
& =25 \% \times 27,19 \text { Ton } \\
& =6,8 \text { Ton }
\end{aligned}
$$

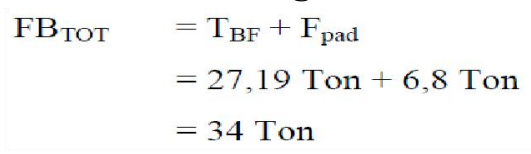

So, the total tonnage of the press machine needed in the bending process is 34 tons with the actual tonnage of the press machine used is 110 tons.

\section{CONCLUSION}

The process of making the Rear AxleBumper Bracket RHstarts with the preparation of materials anddrawings. After that, the formation process is done by blanking, then do the bending(bending)to the lower part and do the drawing for the upper part. After being formed, QC is carried out which is followed by welding using the type of spot welding (spot welding). After welding, QC is carried out. Followed by theprocess is painting carried out using powder coating with the dyeing method.Based on the results of calculations on the Bumper Rear Axle RH Lower Part, the blanking process can be carried out with a total loading of 84.09 Tons with an added backup force of 8.41 Tons so as to produce the capacity of themachine Press needed for the blanking process, which is 120.25 Tons. with the actualmachine press used is 110 tons. For the bending process, it can be done with a total bending force of 27.19 tons with the addedforce pad in the bending process of 6.8 tons so that the total force on the Press machine needed for theprocess bending is 34 tons with the actualmachine. press used is 110 tons.

\section{REFERENCES}

[1] China Brill Special Steel. SPH440 OD Specification of Material.

[2] Ardhayananta, Hosta. et al. Effect of Cold Working on Corrosion Resistance of AISI 1020 Hot Dip Galvanizing Coating in $\mathrm{NaCl}$ Media. Surabaya: Sepuluh Nopember Institute of Technology Surabaya.

[3] Ardian, Aan. 2012. Theory of Material Formation. Yogyakarta: Yogyakarta State University

[4] Boljanovic, Vukota. 2004. Sheet Metal Forming Processes and Die Design. New York : Industrial Press

[5] Suryadi, VY. 2013. The Effect of Material Thickness and Clearance Progressive Dies on the Quality of Ring M7 Products. Surakarta: Eleven March University.

[6] Saputro, Adian Wahyu. 2016. Design and Build of Automatic Bending Machine for 8mm Diameter Begel (Tool Testing). Palembang: Sriwijaya State Polytechnic.

[7] Benson, Steve D. 1997. Press Brake Technology: A Guide to Precision Sheet Metal Bending. Society of Manufacturing Engineers. ISBN 978-0-87263-483-1.

[8] Bayuaji, Alfasian. 2018. Analysis of Rolling Making on the Bending Side of $60 \mathrm{~mm}$ Based on Solidworks Software on Village Cars with the Press Roll Dies Method. Semarang: Semarang State University.

[9] Firnandes, Ekki. 2015. Design Progressive Tool for Producing Keyhole Base (Test Process). Palembang: Sriwijaya State Polytechnic.

[10] Permadi, Hendaru Ajie Anom. 2017. Redesign and Design of Spot Welding Mechanism of Tungsten Electrodes with a Microwave Oven Transformer with a Capacity of 2-3 Volts. Malang: University of Muhammadiyah Malang.

[11] Fachruddin. et al. 2016. The Effect of Electric Current Variations in Spot Welding on Shear Strength, Hardness and Microstructure of AISI 304 Stainless Steel Dismillar Connections with ST 41 Low Carbon Steel. Malang: State University of Malang.

[12] Rizza, Muhammad Akhlis. 2014. Analysis of Blanking Process with Simple Press Tool. Malang: State Polytechnic of Malang

[13] Cahyadi, Dadi. et al. 2014. Analysis of Calculation of Mechanical Forces in the Manufacturing of Upper Arm Bracket Automotive Components. Banten: Serang Raya University. 